\title{
A. Polemiki / Polemiky
}

Historia Slavorum Occidentis

2015, nr 2(9)

ISSN 2084-1213

DOI: $10.15804 /$ hso150213

\section{EDWARd SKIBIŃSKi (PoZNAŃ)}

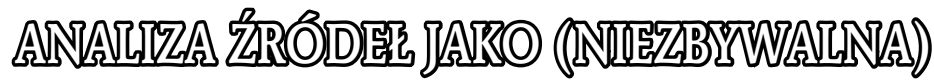 PODSTAWA WARSZTATTU RUISTORSYRA, NA

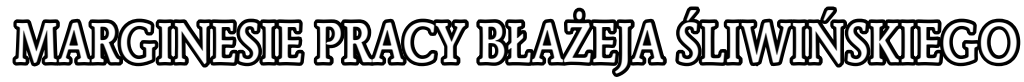

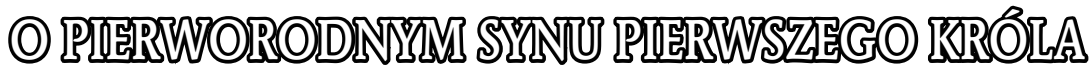 POLSTE}

Dzięki wydanej niedawno pracy Błażeja Śliwińskiego Bezprym znalazł się w grupie tych naszych władców, którzy doczekali się monografii ${ }^{1}$. Fakt ten mógłby cieszyć, gdyby dotychczasowy brak tego rodzaju pracy był spowodowany względami pozamerytorycznymi. Tak jednak nie jest. Brak szerszego opracowania biografii Bezpryma wynikał ze skąpej ilości zachowanych źródeł, w których też niewiele miejsca zostało poświęcone tej postaci.

Czy jednak coś się w tym zakresie zmieniło? Poszerzenie bazy źródłowej naszych najstarszych dziejów przeważnie wynika z odkrycia nowych źródeł archeologicznych. W tym jednak przypadku nie może być o tym mowy. Trudno zakładać, by źródła archeologiczne mogły nam coś dopowiedzieć na temat Bezpryma. Jest to bowiem postać $\mathrm{w}$ dużym stopniu efemeryczna. $Z$ okresu jego panowania nie zachowały się nawet monety, ani pieczęci z jego imieniem. Zobaczmy zatem jak poradził sobie z tą sytuacją pierwszy monografista tego Piastowicza B. Śliwiński.

${ }_{1}$ B. Śliwiński, Bezprym pierworodny syn pierwszego króla Polski (986-zima/wiosna 1032), Kraków 2014. 
Spróbujmy prześledzić argumentację autora, konfrontując ją z podstawą źródłową. Po pracach Hydena White’a historycy często przyjmują interpretację swojej pracy jako tworzenie narracji, o której odniesieniu do rzeczywistości trudno na poważnie mówić. Za takim stanowiskiem zdaje się opowiadać B. Śliwiński pisząc:

„Przedstawiana biografia księcia Bezpryma jest więc tak naprawdę niczym innym jak prezentacją poglądów historiografii (czyli konkretnych badaczy), jej wyobrażeń, jak mogło biec życie Bezpryma, a wszystko to jest projekcją wielu różnych punktów widzenia z „wmontowaną” w nie hipotetyczną rolą Bezpryma"2.

Przy takim założeniu autor pozornie, acz konsekwentnie nie musiał się więc odnosić do materiału źródłowego. Idąc za Historyką Marcelego Handelsmana, mielibyśmy tu do czynienia z kompilacją, której autor zestawia i łączy zastane $\mathrm{w}$ dotychczasowej literaturze poglądy innych badaczy. Jednak autor ma większe i bardziej tradycyjne ambicje, pisze bowiem dalej tak:

„Jak to bowiem rozumieć: pierworodny, legalny, zrodzony z małżeństwa dynastycznego syn Bolesława Chrobrego był uzurpatorem? A może jednak nie uzurpatorem, a ofiarą wydarzeń od siebie niezależnych?"3. Jak zatem widać autor, wbrew wcześniejszym deklaracjom, wraca tu do starej formuły Leopolda von Ranke „wie es eigentlich gewesen”?

Zastanawiając się nad sposobem prezentacji postaci Bezpryma przyjętym przez B. Śliwińskiego, wypada uwzględnić również wymagania stawiane przez wydawców. Jak można domniemywać, w trosce o czytelnika, domagają się oni uproszczenia argumentacji historycznej przez autorów wydawanych książek historycznych. Efektem tej tendencji jest druk opracowań, które $z$ tego właśnie powodu, tj. braku argumentacji opartej na analizie źródeł łatwo poddać krytyce. Pomijanie źródeł i ich analizy skutkuje uproszczeniami. Sprawia też, że autorzy nie konfrontują swoich tez z materiałem źródłowym. Tymczasem nasze najstarsze dzieje są badane w oparciu o skąpy materiał, jeśli chodzi o źródła pisane i rozszerzający się w zakresie źródeł archeologicznych, antropologicznych i genetycznych. Dochodzą do tego prace konserwatorów zabytków i specjalistów od poszczególnych zachowanych artefaktów, np. metalurgów (drzwi gnieźnieńskie). Nasze najstarsze dzieje powinny być opracowywane więc poprzez analizy zachowanych źródeł, a nie bez nich. Nie

\footnotetext{
2 Tamże, s. 32.

3 Tamże, s. 33.
} 
dotyczy to jednak tylko tego okresu historii. Wszelkie kłamstwa historyczne mogą (zwłaszcza w historii najnowszej) istnieć za sprawą pomijania źródeł. Tezy historyczne historyków, dziennikarzy, prawników, polityków, duchownych itd. powinny być brane pod uwagę wyłącznie wtedy, kiedy są zaopatrzone $\mathrm{w}$ analizę źródeł, na których deklaratywnie się opierają.

Zobaczmy, jaki wynik dała praca nad rekonstrukcją dziejów Bezpryma według wskazanej przez autora metodyki. Ważną częścią każdej, a więc i omawianej tu monografii naukowej jest wstęp, który przynosi w tym przypadku omówienie źródeł i najważniejszej literatury przedmiotu. Jednak w dalszych rozdziałach autor koncentruje się przeważnie na różnych opracowaniach, ważąc ich wartość i próbując je dopasować do siebie.

Widać tu już metodę zastosowaną przez autora - płynne przechodzenie od źródeł do opracowań. Chodzi tu, jak się zdaje, o prześledzenie rozmaitych stanowisk, zajmowanych na przestrzeni wieków wobec Bezpryma. Takie podejście prowadzi jednak do zagubienia i zatarcia odrębnego charakteru źródeł historycznych i opracowań.

Pierwszy rozdział biografii autorstwa B. Śliwińskiego nosi tytuł „Rodzice i pierwsze lata". Odpowiednią podstawę źródłową z epoki stanowi wzmianka w Kronice niezawodnego Thietmara:

Duxit hic Rigdagi marchionis filiam, postmodum dimittens eam, et tunc ab Ungaria sumpsit uxorem, de qua habuit filium Besprim nomine, similiter expellens eam ${ }^{4}$.

Fragment ten można przetłumaczyć tak:

„Poślubił on córkę Rykdaga margrabiego, potem ją odsyłając i wtedy wziął żonę z Węgier, z której miał syna imieniem Bezprym, podobnie wypędzając ją"5.

Cały rozdział poświęcony tym zagadnieniom B. Śliwiński podsumowuje takimi uwagami: „Pozostaje tylko skorzystać z informacji biskupa Thietmara, że węgierska żona Bolesława Chrobrego, moim zdaniem Karolda, odesłana została po urodzeniu Bezpryma do swojej węgierskiej rodziny, ale sama. Urodzony przez nią syn Bezprym pozostał pod opieką ojca”.

Wymowa fragmentu kroniki Thietmara jest dosyć jednoznaczna. Chrobry odesłał żonę de qua habuit filium Besprim. Syna zatem zatrzymał. Wydaje się, że w literaturze przedmiotu dyskutuje się ten problem bez wymaganego

4 Thietmari Merseburgensis episcopi Chronicon, wyd. R. Holtzmann, Berlin 1935, MGH SRG SN, t, 9, s. 198.

${ }^{5}$ Tłumaczenie własne.

${ }^{6}$ B. Śliwiński, Bezprym, s. 59. 
pochylenia się nad tekstem Thietmara. Kronikarz wyraźnie oddziela matkę od syna. Stąd wiemy, że wygnanie dotyczy tylko jej. Można by uznać jednak, $\dot{z ̇ e}$ Thietmar nie wyraził się dokładnie. Pozostaje też pytanie, dlaczego jest to ostatnia wzmianka o Bezprymie w tej kronice? Gdyby, jak chce B. Śliwiński, miała to być siostra Sarolty Białej Knegini, dlaczego nas o tym kronikarz nie poinformował, kiedy pisał o niej ${ }^{7}$. Dlaczego będąc wszak biskupem, nic nie wspomina o późniejszych wyborach Bezpryma.

Thietmar zna ponadto Bezpryma $z$ imienia, wspomina go jednak tylko raz, kiedy pisze o jego narodzinach.

B. Śliwiński rozpatruje tu jeszcze kilka zagadnień. Uporządkujmy je od strony formalnej. Zacznijmy od imienia Bezpryma stanowiącego hapaxlegomenon w imiennictwie Piastów. Trzeba się zgodzić z B. Śliwińskim, który odrzucił argumentację Wandy Santarius, dotyczącą pochodzenia tego imienia, jako opartą na zbyt małej podstawie źródłowej. Jednak sam B. Śliwiński, w tym wypadku zgodnie zresztą z postulowaną przez siebie metodą kompilacji, takiej podstawy nie dostarczył. Hipoteza o węgierskim pochodzeniu imienia Bezprym jest prawdopodobna, ale wymaga dalszych dociekań.

Następnym problemem jest pochodzenie matki Bezpryma. Tu jak dotąd jesteśmy pozbawieni oparcia w materiale źródłowym. Pewną podstawę może dostarczyć studium imienia Bezprym, pod warunkiem, że imię to powtarzałoby się w jakimś rodzie. Inni dyskutanci oparli argumentację na późniejszych źródłach - Kronice węgiersko-polskiej ${ }^{8}$, traktując wspomnianą tam żonę władcy węgierskiego Gejzy, siostrę Mieszka I Adelajdę, jako ślad, którego źródłem jest historia żony Bolesława Chrobrego.

Kolejny etap życia Bezpryma ma oświetlać Żywot św. Romualda pióra Piotra Damianiego9. Jest to historia jego dorosłych już wyborów. Na podstawie Żywota św. Romualda przyjmuje się, że został mnichem. Oto stosowny cytat $z$ tego źródła:

Habebat autem equum satis egeregium, quem sibi Busclavi Sclavonici regis filius dederat, factus ab eo monachus ${ }^{10}$.

Fragment ten można przetłumaczyć tak:

7 Thietmar, 8,4.

8 B. Hóman, König Stephan I. Der Heilige. Die Gründung des ungarischen Staates, übersetzt von Hildegard von Roosz, Breslau 1941.

9 Petri Damiani Vita beati Romualdi, wyd. G. Tabacco, Roma 1957.

10 Tamże, s. 54-55. 
„Miał zaś konia bardzo wspaniałego, którego mu syn Bolesława słowiańskiego króla dał, uczyniony przez niego mnichem" ${ }^{11}$.

Interpretatorzy dodali do tego tekstu kilka założeń, które nie są oczywiste w świetle tekstu Damianiego. Przyjmują zatem, że Busclavus Sclavonicus rex - „Bolesław słowiański król” to Bolesław Chrobry, a jego syn, który darował św. Romualdowi konia, to Bezprym. Już jednak Anatol Lewicki wskazywał, że mógł to być nieznany nam syn Chrobrego pochodzący z nieprawego łoża ${ }^{12}$. Wielość kombinacji uczonych wynika $z$ niejasnego $\mathrm{w}$ tym miejscu tekstu dyskutowanego źródła. Jednak nie przeszkadza to monografiście Bezpryma zająć takie oto stanowisko:

„Nie ma obecnie w polskiej historiografii wątpliwości, że wzmianka o „królu słowiańskim Bolesławie” dotyczy Bolesława Chrobrego. Ze sposobu narracji „Żywota św. Romualda" jasno też wynika, że syn Bolesława Chrobrego był, obok imiennie wymienionego Tammusa, w grupie owych bezimiennie już wspomnianych „Teutonów” (czyli osób towarzyszących Ottonowi III), których ś.w. Romuald po upadku Tivoli także namówił do porzucenia życia świeckiego i przyłączenia się do eremitów"13.

Argumentacja ze sposobu narracji brzmi poważnie, nie została jednak poprzedzona gruntownymi analizami. Spróbujmy uzupełnić ten brak. Romuald w opowiadaniu Piotra Damiani odwozi pozyskanych ludzi do Pereum jadąc na osiołku, którego wymienił za konia otrzymanego od syna króla słowiańskiego Bolesława. Jest to jakaś imitatio Christi ${ }^{14}$. Romuald jedzie na osiołku nie po raz pierwszy - vir venerabilis hoc ipsum animal libentius equitabat ${ }^{15}$ - „mąż szlachetny na tym właśnie zwierzęciu chętnie podróżował”. Objaśnienie dotyczy więc faktów z przeszłości, tj. zamiany konia na osiołka oraz praktyki, która trwała już czas dłuższy - używania osiołka do podróży. O osiołku Romualda nic nie wie Bruno z Kwerfurtu. Sam podróżuje konno.

Jeśli w ujęciu Żywota Romuald pragnie tu naśladować wjazd Jezusa do Jerozolimy na osiołku, to musi to budzić wątpliwości, co do autentyczności tego motywu. Założenia Brunona (również ucznia św. Romualda) zakładają,

11 Tłumaczenie własne.

12 A. Lewicki, Mieszko II, s. 87-208, Rozprawy i Sprawozdania z Posiedzeń Wydziału HistorycznoFilozoficznego Akademii Umiejętności 5 (1876), s. 134-135.

13 B. Śliwiński, Bezprym, s. 62.

${ }_{14}$ Petri Damiani, s. 55. Nimio quippe Redemptoris nostri desiderio, qui aselle tergo consederat, vir venerabilis hoc ipsum animal libentius equitabat.

15 Tamże, s. 55. 
że nie można zostać świętym przez proste powielanie zachowania już uznanych świętych, bądź samego Chrystusa ${ }^{16}$. Tymczasem w wersji Damianiego zarówno Romuald, jak i sam Bruno realizują świętość w ten właśnie sposób. Romuald naśladować ma Chrystusa, Bruno zaś św. Bonifacego. Podobnie jak Bruno, Benedykt z Benewentu również miał jeździć konno bądź podróżować pieszo. Tak to przynajmniej przedstawia sam Bruno z Kwerfurtu, naoczny świadek tych zdarzeń. Romuald miał być wzorem dla Benedykta, był też mistrzem Brunona. Sprawę można łatwo wyjaśnić, przesuwając ten motyw na okres późniejszy po wydarzeniach przedstawionych w Vita 5 fratrum. Tłumaczyłoby to, dlaczego Bruno nic o tym nie wie. W relacji Piotra Damianiego nie ma też miejsca na charyzmatyczną postać Benedykta z Benewentu, którą w jego relacji wyprzedza przydany mu do pomocy Jan. U Damianiego postać Brunona nie została ponadto powiązana z Benedyktem i Janem i ich misją do Polski.

Na czym ta misja miała polegać? Jak pisze B. Śliwiński, Piotr Damiani i Bruno z Kwerfurtu różnie przedstawiają przyczyny powstania eremu w państwie Chrobrego:

„O ile Damiani inicjatywę przywołania eremitów do Polski składał w ręce Chrobrego (wiadomość o poselstwie od tego księcia w okresie pobytu cesarza Ottona w Rawennie), o tyle Brunon z Kwerfurtu silnie podkreślał, że była to inicjatywa cesarza Ottona III"17.

Jaka jest więc treść przekazu Piotra Damianiego? Oto tekst łaciński jego relacji:

XXVIII. Interea, Romualdo in Pereo habitante, Busclavus rex preces imperatori direxit ut sibi spirituales viros mitteret qui regni sui gentem ad fidem vocarent ${ }^{18}$.

Można to przetłumaczyć w ten sposób:

„XXVIII. Tymczasem, kiedy Romuald mieszkał w Pereum Bolesław król prośby do cesarza skierował, aby mu mnichów przysłał, którzy lud jego królestwa zachęcą do wiary" ${ }^{19}$.

16 Por. M. Sosnowski, Kategorie związane z misją i męczeństwem w pismach św. Brunona $z$ Kwerfurtu, [w:] Cognitioni gestarum. Studia z dziejów średniowiecza dedykowane Profesorowi Jerzemu Strzelczykowi, red. D. A. Sikorski, A. M. Wyrwa, Poznań-Warszawa 2006, s. 205-230.

17 B. Śliwiński, Bezprym, s. 99.

18 Petri Damiani, s. 61.

19 Tłumaczenie własne. 
Misja do Słowian według relacji Brunona miała być pomysłem Ottona III i samego Brunona, który namówił do tego Benedykta. Z kolei w tekście Piotra Damianiego misja jest wynikiem prośby Chrobrego. Nie łączy tego jednak autor Żywota św. Romualda z wcześniejszym darem od syna króla Bolesława, który winien był wtedy znajdować się wśród mnichów kierowanych przez Romualda. Na prośbę tę reagują tylko dwaj - Jan i Benedykt. Obok tego zdarzenia Damiani wzmiankuje o innym ważnym w tym kontekście zdarzeniu. Otton III wedle Damianiego miał złożyć też Romualdowi obietnicę porzucenia władzy i założenia habitu. Co to za pomysł? Pełniejszą informację znajdziemy w Żywocie Pięciu Braci Brunona z Kwerfurtu. Otton miał obiecać porzucenie władzy w ciągu trzech lat. Potem obiecał „całą duszą nagi podążyć za Chrystusem". W imieniu Romualda odpowiedzieli mu dwaj jego uczniowie - zapewne Benedykt i sam Brunon. Sprawa powraca po wyjeździe Romualda do Istrii. Bruno zapytany przez Benedykta, co pozostało z obietnicy cesarza, odpowiada, że ten chce, aby Benedykt go poprzedzał do kraju Słowian. Misja załamuje się wraz ze śmiercią Ottona III. Stwierdzić to mieli sami oczekujący Brunona eremici.

Piotr Damiani prezentuje więc wersję sprzeczną ze świadectwem Brunona, który ponadto był świadkiem tych zdarzeń. Zamiast inicjatywy cesarza mamy opowieść o prośbie Bolesława Chrobrego do misjonarzy dla chrystianizacji pogan w jego kraju. Ottonowi przypada tu rola pośrednika. Tych braci ma potem prosić Bolesław o wstawiennictwo - chcąc otrzymać koronę $z$ rąk papieża. Tej historii $w$ tekstach Brunona $z$ Kwerfurtu nie znajdziemy. Dlaczego Bolesław nie wykorzystał tu syna, dlaczego nie zwrócił się do samego Ottona, którego prosił o misjonarzy, autor nie wyjaśnia.

Problemem, który porusza B. Śliwiński jest zwlekanie Brunona z podążeniem za Benedyktem i Janem do Polski. Jednak takie zachowanie jest zrozumiałe w ramach jego narracji. Benedykt miał poprzedzać cesarza do kraju Słowian. Dopiero po śmierci cesarza ta część misji stała się niewykonalna. To sprowokowało podróż Benedykta do Rzymu.

Jaka rola przypadała w tym przedsięwzięciu Bezprymowi? Odpowiadając na to pytanie zastrzec się wypada, że stawiamy hipotezy niemające bezpośredniego oparcia w źródłach. Nie wiemy najpierw, czy to Bezprym był darczyńcą, a potem mnichem Romualda. Nie wiemy też, kiedy opowiedziana historia miała miejsce. Przyjmując jednak taką interpretację, musimy włączyć Bezpryma do misji ottońskiej. Jako pierworodny Chrobrego czekałby 
zapewne na samego Ottona $z$ udaniem się do eremu Benedykta i Jana w kraju Bolesława Chrobrego. Na tym etapie musielibyśmy zatem uznać, że przejął się zdarzeniami, które odmieniły państwo jego ojca, a zatem misją i śmiercią Wojciecha oraz wydarzeniami zjazdu roku 1000 i podjął to duchowe przesłanie, które zaprowadziło go do Romualda i jego eremitów. Miał przecież wielki przykład w osobie samego cesarza Ottona.

Próbuje się czasem widzieć w tej roli Mieszka II. Takie stanowisko zdaje się pomijać wymiar dewocyjny tego zagadnienia ${ }^{20}$. Mieszko jakiego znamy nie zadawala się jedną żoną. Doceniając jego rolę jako wodza i polityka, trudno jednak znaleźć argumenty za taką jego duchową aktywnością, która mogłaby sprostać wymaganiom Romualda, a potem Brunona $z$ Kwerfurtu czy Benedykta z Benewentu.

Pisma Brunona pokazują nam innego Chrobrego - władcę zaangażowanego w misję wśród pogan, troszczącego się o eremitów i wspierającego ich finansowo. Według Brunona eremici przyjęli pieniądze od polskiego władcy, ba, Benedykt udał się w podróż do Rzymu, ale został zawrócony przez samego Bolesława z powodu grożącej wojny. To sprawiło, że już niepotrzebne pieniądze oddał. Wysłał jednak z tą misją innego mnicha. Akcja Henryka obejmowała nie tylko zatrzymanie owego mnicha, lecz również biskupa poznańskiego Ungera. Jest to o tyle ważne, że Unger wyruszył w podróż już po męczeńskiej śmierci eremitów. Wolno przypuszczać, że w związku z tą śmiercią udał się do Rzymu.

Podsumowując trudno uznać relację Piotra Damianiego za wierne świadectwo dla okresu działalności Romualda, związanego z Brunonem z Kwerfurtu i Benedyktem z Benewentu. Damiani przypisuje Romualdowi inicjatywy, które według Brunona - naocznego świadka - miały być podejmowane przez cesarza Ottona. Pomija rolę Benedykta z Benewentu w tym okresie działalności Romualda. Prezentowany przez niego model świętości jest sprzeczny z poglądem reprezentowanym w Vita 5 fratrum. Jeżeli uznać informację o staraniach Chrobrego o koronę w Rzymie zawartą w Vita Romualdi Piotra Damianiego za mającą jakiś związek z rzeczywistością, to trzeba stwierdzić, że eremici podjęli się tej misji skoro, jak wiemy z tekstu Brunona $z$ Kwerfurtu, Benedykt przyjął pieniądze od Chrobrego. Jest to jednak

\footnotetext{
20 S. Syty, Mieszko II czy Bezprym mnichem u św. Romualda, [w:] Nihil superfluum esse. Studia z dziejów średniowiecza ofiarowane Profesor Jadwidze Krzyżaniakowej, red. J. Strzelczyk, J. Dobosz, Poznań, 2000, s. 101-109.
} 
wersja sprzeczna z całą treścią Żywota pięciu braci. Przedstawione tam stosunki eremitów i Bolesława Chrobrego nie mają wymiaru politycznego. Polski władca już po śmierci eremitów okazuje się sceptyczny wobec cudownych zdarzeń, które po niej nastąpiły. Bruno nieraz wskazuje na religijne zaangażowanie Bolesława Chrobrego w sprawy eremitów. Polski władca jest wymagającym opiekunem ich misji.

Jako pierwszy sprawę zamordowania eremitów połączył z ówczesną polityką Paweł Stróżyk ${ }^{21}$. Przeoczenie politycznego wymiaru tych wydarzeń przez badaczy wcześniej zajmujących się tą tematyką wydaje się zaskakujące. Sam B. Śliwiński polemizując z P. Stróżykiem pominął całkowicie przeprowadzoną przez tego ostatniego analizę tekstu Żywota Pięciu Braci ${ }^{22}$. Zamiast tego napisał:

„Wiadomo, że na czele morderców stał ktoś, kogo już wcześniej Bolesław Chrobry oddelegował do usługiwania eremitom. Poszukiwano go w wyższych warstwach społecznych widząc w nim włodarza, rycerza $z$ dworu, nawet kasztelana z Międzyrzecza (teraz doszedł Bezprym). Do wszystkich tych domysłów ( $z$ wyjątkiem rzecz jasna Bezpryma, bo to pomysł ostatni) odniósł się swego czasu krytycznie H. Łowmiański, Religia Słowian, s. 308, przyp. 796, który (przywołując także literaturę przedmiotu) stwierdził, że ze źródeł wynika, że dokonali napadu ludzie niskiej kondycji, służebnej. Jest to jedyna słuszna opinia"23.

Taka argumentacja, pozbawiona analizy źródeł, mieści się poza granicami metody historycznej. W przeciwieństwie do Henryka Łowmiańskiego, B. Śliwiński mógł jednak zapoznać się z pracą P. Stróżyka, czego najwyraźniej nie uczynił. W swojej polemice nie odniósł się bowiem do żadnego $z$ argumentów poznańskiego uczonego. Poza odwołaniem się do autorytetu i, jak sam zaznaczył, ,jedynie słusznej opinii”, posłużył się jeszcze kategorią prawdopodobieństwa:

„Nawet gdyby Bezprym był zamieszany w tę sprawę, to mamy wierzyć, że pierworodny syn księcia Polski Bolesława Chrobrego osobiście nocą mordował na odludziu eremitów?" ${ }^{24}$.

Zasada ta opiera się, jak sam autor przyznaje, na wierze w to, że pochodzenie chroniło od występków. Jest to jednak wiara sprzeczna z naszą wiedzą historyczną (por. św. Wacław, św. Stanisław itd.)

${ }^{21}$ P. Stróżyk, Śmierć eremitów w relacji Brunona z Kwerfurtu, Roczniki Historyczne 69 (2003), s. 7-31.

22 B. Śliwiński, Bezprym, s. 123 i 124.

23 Tamże, s. 124.

24 Tamże. 
W artykule P. Stróżyka teza o sprawstwie Bezpryma ma charakter hipotezy. Opiera się jednak na starannej analizie źródeł. B. Śliwiński próbuje ją zwalczyć w oparciu o jakąś zasadę prawdopodobieństwa. Do tego dodaje tezę H. Łowmiańskiego - ponownie bez odwołania się do źródeł. Warto zauważyć, że uwagi P. Stróżyka są lepiej osadzone w materiale źródłowym niż koncepcja o mnichostwie Bezpryma u św. Romualda.

Truizmem jest stwierdzenie, że rekonstrukcje historyków powinny się opierać na materiale źródłowym. W przypadku naszych najstarszych dziejów jest on nadzwyczaj skąpy. Tym bardziej nie wolno go pomijać. Z tymi zastrzeżeniami spróbujmy podjąć raz jeszcze ten temat. Naszym bezpośrednim świadkiem wydarzeń w Italii jest Bruno z Kwerfurtu. Przedstawił je w Żywocie Benedykta i Jana i ich towarzyszy, znanym jako Żywot pięciu braci męczenników. Głównym bohaterem tego utworu jest Benedykt $z$ Benewentu duchowy mistrz Brunona. Żywot przedstawia drogę rozwoju Benedykta od poszukiwań mistrzów mistycznych do uzyskania samodzielności i męczeńskiej śmierci. Ostatnim mistrzem jest Romuald. Benedykt jednak oddala się od niego i dopiero od Brunona dowiaduje się, że ich mistrz porzucił klasztor i wyjechał do Ilirii. Benedykt zostaje namówiony przez Brunona do udziału w misji do Polski, której patronuje sam cesarz Otton III. Ma on poprzedzać Ottona III. O Brunonie mamy jeszcze kilka świadectw. Thietmar pisze zwięźle na temat Brunona. Pomija zupełnie sprawę Benedykta $z$ Benewentu i jego towarzyszy. Wzmiankuje tylko przyjaźń Brunona z Ottonem III. Jak na znajomego Brunona $z$ Kwerfurtu podał nam bardzo mało wiadomości.

Spróbujmy podsumować to, co nam źródła mówią o interesujących nas zdarzeniach. Bruno pisze w Żywocie Pięciu Braci, że wysłany przez eremitów został po drodze wraz z biskupem Ungerem:

quia discordia magna cum rege Saxonum erat, dum timetur, ne in damnum sui imperii illorum cursus foret, cum satis bono Vvngero episcopo in itinere comprehenditur, et missus Parthenopolim, in monasterio sub diligenti custodia tenetur ${ }^{25}$.

„Ponieważ wielka niezgoda z królem Saksonów była, kiedy był w obawie, aby na szkodę jego władzy ich podróż nie była, $z$ bardzo dobrym biskupem Ungerem jest złapany w drodze i wysłany do Magdeburga, w klasztorze pod uważną strażą jest trzymany"26.

\footnotetext{
${ }^{25}$ Bruno Querfurtensis, Vita quinque fratrum eremitarum [seu] Vita uel passio Benedicti et Iohannis sociorumque suorum, wyd. J. Karwasińska, MPH SSN IV, 3, Warszawa 1973, s. 72. ${ }_{26}$ Tłumaczenie własne.
} 
Henryk II, wedle tej relacji, bał się, żeby ich podróż do Rzymu nie okazała się szkodliwa dla jego władzy, dlatego zdecydował się na zatrzymanie obu. Ciekawe, że ta historia nie znalazła żadnego odbicia w kronice Thietmara. O staraniach Bolesława o koronę w Rzymie pisze też Damiani. Jest to narzucająca się interpretacja tych zdarzeń. Interesy władców świeckich w Rzymie mogły obejmować również starania o koronę. Unger udał się do Rzymu już po śmierci braci. Zamordowano ich na terenie jego diecezji. Wolno się domyślać, że jego wyjazd był powiązany również z tym wypadkiem. Skoro tak, to wolno zatrzymanie poznańskiego biskupa również wiązać z tym zdarzeniem. Zastanówmy się na chwilę, czy mógł to być inny powód, np. staranie Chrobrego o koronę. Musielibyśmy wtedy uznać Ungera za wysłannika, który mógł pozyskać do takiej koncepcji papieża wbrew Henrykowi II. Wtedy zatrzymanie Ungera byłoby uzasadnione. Jednak Unger został zatrzymany $z$ eremitą - trudno jest więc bronić innego stanowiska niż to, że Unger jechał poinformować papieża o śmierci Benedykta i jego towarzyszy. Jaką szkodę mogło to wyrządzić Henrykowi II? To, co wydaje się nie podlegać dyskusji, to porwanie biskupa wykonane z polecenia Henryka II. Jak zauważa P. Stróżyk w relacji Brunona, pierwotnym zamysłem przybyłej do eremu grupy było uprowadzenie eremitów. To zadanie uniemożliwiła postawa Jana i Benedykta. Musimy tu podkreślić aktywną rolę obu, gdyż Jan wedle narracji Brunona odpowiada po konsultacji z Benedyktem. Zdaje się, że zbrodnia była wynikiem zetknięcia się spiskowców z reakcją obu charyzmatycznych postaci. Zwłaszcza, że Jan nie uląkł się też groźby śmierci.

Oceniając opowieść Brunona, zwrócić wypada uwagę na fakt, że poskąpił on informacji o mordercach eremitów, mimo że, jak przyznaje, miał z nimi do czynienia i to na ich relacji oparł swoją opowieść. W tym pominięciu Bruno postępuje podobnie jak Thietmar, który całą historię wyeliminował ze swojej narracji. Taka strategia narracyjna wynikać musiała z ważnych powodów. Te powody musiały być związane z osobami postawionymi wysoko w hierarchii. Bezprym, pierworodny Bolesława Chrobrego, wydaje się tu kandydatem oczywistym. Obrona Bezpryma w wykonaniu B. Śliwińskiego, oparta na jego randze, jest paradoksalnie oparta na tych samych motywach. Jeżeli przyjmiemy tezę o celowym przemilczeniu tej sprawy np. przez Thietmara, to musimy zapytać o przyczyny takiej postawy. Co zjednoczyło obie strony? Czy była to ochrona czyjegoś dobrego imienia? 
Należy jednak podkreślić, że, podobnie jak P. Stróżyk, traktuję tę koncepcję jedynie jako hipotezę. Brak bowiem materiału źródłowego dla mocniejszego postawienia tezy o przynależności Bezpryma $\mathrm{w}$ jakimkolwiek okresie jego życia do stanu duchownego. Bezprym dający konia i Bezprym pokutujący za zbrodnie trochę do siebie nie przystają. Relacja Damianiego jest przy tym uboga w szczegóły i w wielu miejscach ewidentnie fałszywa. Jest też sprzeczna $z$ opowiadaniem o tych zdarzeniach samego Brunona $z$ Kwerfurtu. Na spekulacje w sprawie Bezpryma pozwala $z$ drugiej strony potwierdzona źródłowo informacja o porwaniu Ungera i eremity wysłanego do Rzymu. Choć tu też, naśladując argumentację B. Śliwińskiego, można by powiedzieć, że święty Henryk II nie mógłby być zamieszany w takie działania.

Ostatni rozdział swojej książki poświęcił B. Śliwiński najlepiej oświetlonemu przez źródła okresowi życia Bezpryma, który przypadł na lata po śmierci Bolesława Chrobrego. Głównym źródłem do opracowania tego okresu są dla Autora opowiadania zamieszczone w Żywocie Konrada pióra Wipona. Zanim przejdziemy do tego tekstu zobaczmy, co mówią inne źródła. O dalszych losach Bezpryma znajdujemy wzmianki w Rocznikach hildesheimskich. Annales Hildesheimenses przynoszą nam zwięzłą opowieść relacjonującą pojawienie się Bezpryma w grze politycznej:

Imperator cum parvo Saxonum exercitu Sclavos autumnali tempore invasit et Mysachonem, diu sibi resistentem, regionem Lusizi cum aliquot urbibus et preda, quae prioribus annis in Saxonia facta est, restituere pacemque iuramento firmare coegit, Qui Mysecho post mensis tantum spatium a fratre suo Bezpriemo subita invasione proturbatus et ad Odalricum in Beheim fugere est compulsus. Sed idem Bezprimo imperatori coronam cum aliis regalibus, quae sibi frater eius iniuste usurpaverat, transmisit ac semet humili mandamine per legatos suos imperatori subditurum ${ }^{27}$.

Tłumaczenie tego tekstu brzmi następująco:

„Cesarz z małym wojskiem Sasów jesienną porą najechał Słowian i Mieszka, który długo stawiał mu opór, zmusił do zwrócenia kraju Lusizi z kilkoma miastami i zdobyczą, która w poprzednich latach została uczyniona i do umocnienia pokoju przysięgą. Ten Mieszko po okresie zaledwie miesiąca przez brata swego Bezpryma nagłym atakiem przepędzony i zmuszony do ucieczki do Udalryka do Czech. Lecz tenże Bezprym przesłał cesarzowi koronę z innymi odznakami królewskimi,

27 Annales Hildesheimenses, wyd. G. Waitz, Hannover 1878, s. 36. 
które brat jego niesprawiedliwie przywłaszczył sobie, i w pokornym liście obiecał przez swoich posłów poddać się cesarzowi" ${ }^{28}$.

Rocznikarz opowiada tu o dwóch atakach na Mieszka. Pierwszy cesarski i drugi po miesiącu dokonany przez starszego brata polskiego władcy Bezpryma. Oba ataki są niepowiązane ze sobą. Klęska Mieszka zdaje się wynikać z krótkiego okresu między dwoma atakami. Polski władca, osłabiony klęską zadaną przez cesarza ulega atakowi brata. Ten napada na niczego niespodziewającego się Mieszka II i wygania go z kraju. Objąwszy władzę odsyła insygnia królewskie cesarzowi. Taka lojalność zdaje się nie być przypadkowa. Bezprym musi szukać sojuszników. Te same Roczniki hildesheimskie tak to dalej przedstawiają:

Ind. 15, 1032. Chuonradus imperator natale Domini Gosleri, pascha vero Seliganstad celebravit. Hoc anno Bezbriem ob inmanissimam tirannidis suae sevitiam a suis, et etiam non sine fratrum suorum machinatione, interfectus est. Sed Miseko statim domum rediit; qui cognoscens, sibi propter immoderatam sui insolentiam, quam prioribus annis exercuit, omnia quae perpessus est merito evenisse, legatos suos ad imperatorem destinavit tempusque semet prestandi condigneque satisfaciendi postulavit. Et postmodum imperatore consentiente Merseburg venit et semet Non.Iuli in imperatoriam potestatem, coronae scilicet ac tocius raegalis ornamenti oblitus, humiliter dedit. Quem imperator clementius, quam ipse opinaretur, suscepit eique et eius patrueli, cuidam Thiedrico, regnum, quod ipse solus ante possederat, divisit; quod ipse tamen postea solus iterum sibi usurpavit ${ }^{29}$.

Tłumaczenie tego fragmentu brzmi:

„Indykcji 15, 1032 Cesarz Konrad Urodziny Pańskie w Goslarze, Wielkanoc zaś w Selingstadt świętował. Tegoż roku Bezprym z powodu ogromnego okrucieństwa swojej tyranii został zabity przez swoich, i również nie bez wpływu swoich braci. Lecz Mieszko natychmiast do domu powrócił. Rozumiejąc, że zdarzyło mu się słusznie, co przeżył w poprzednich latach, skierował swoich posłów do cesarza domagając się /wyznaczenia/ czasu przybycia i stosownego zadośćuczynienia. A następnie za zgodą cesarza przybył do Merseburga i oddał się pokornie w nony lipca pod władzę cesarza, zapomniawszy o koronie i całej ozdobie królewskiej. Cesarz go, łagodniej niż on sam sądził, przyjął i jego stryjowi pewnemu Thidrykowi królestwo podzielił. On to później sam znowu dla siebie zawłaszczył”30.

${ }^{28}$ Tłumaczenie K. Abgarowicz, Wybór źródeł do historii Polski średniowiecznej, t. 1 (Społeczeństwo i państwo polskie do połowy XIII wieku), oprac. G. Labuda, B. Miśkiewicz, s. 76 (z moimi poprawkami).

29 Annales Hildesheimenses, s. 37.

${ }^{30}$ Tłumaczenie własne. 
Mieszko tymczasem we współpracy z młodszym bratem odzyskuje władzę. Wspólnie mieli się też przyczynić do zabicia Bezpryma. Pomóc tu miały jakieś okrucieństwa, których miał się dopuścić. Pomoc brata, zapewne Ottona, nie oznacza tu jakichś politycznych ambicji tego ostatniego. Mieszko zatem powraca natychmiast do domu i pozostaje monarchą.

Jednak być może pod wpływem klęsk stawia się przed cesarzem dla zadośćuczynienia. Rocznikarz nie pisze bezpośrednio o odbyciu pokuty przez Mieszka. Pisze, że Mieszko miał zrozumieć, że wszystko, co przeżył wydarzyło mu się „słusznie”. Nie ma też mowy o zrzeczeniu się korony, a tylko o zapomnieniu o niej - coronae scilicet ac tocius raegalis ornamenti oblitus. Na pokutę dostaje jako współrządcę jakiegoś Thiedryka, zapewne wnuka Mieszka I. Nie na długo zresztą, bo Mieszko II ponownie powrócił do władzy. Opowiadanie rocznikarskie przynosi informacje obserwatorów zewnętrznych, którzy podejmują pewien trud odtworzenia dziejów upadku Mieszka II. Subita invasio Bezpryma dokonana miała zostać samodzielnie. Również jego upadek został spowodowany jego postępowaniem.

Kolejnym źródłem, które wspomina o Bezprymie są Annales Altahenses Maiores. Znajdujemy tu pod r. 1031 następująca wzmiankę:

Eodem vero anno eundem Misaconem Bezbrien, frater eius, de Pollonia eiecit et in Beheim ad Udalricum ducem fugere fecit ${ }^{31}$.

Tłumaczenie tego zdania brzmi:

„W tym zaś roku tego Mieszka Bezprym jego brat z Polski wyrzucił i zmusił do ucieczki do Czech do księcia Oldrzycha" ${ }^{2}$.

Kontynuuje te uwagi notatka zapisana pod r. 1032:

Bezbriem a suis occisus, Misaco ab imperatore est in locum restitutus ${ }^{33}$.

Na język polski można to zdanie tak przetłumaczyć:

„Bezprym przez swoich zabity. Mieszko przez cesarza przywrócony na miejsce"34.

Roczniki przynoszą powtórzenie informacji poprzedników bez własnych dodatków. Interesujące nas zdarzenia zostały później szerzej opracowane przez autora zwanego Annalista Saxo. Pewną odmianę narracji rocznikarskiej znajdujemy tylko w opisie klęski Bezpryma:

\footnotetext{
${ }^{31}$ Annales Altahenses Maiores, wyd. W. von Giesebrecht, Hannover 1891, s. 18.

32 Tłumaczenie własne.

${ }^{33}$ Annales Altahenses Maiores, s. 18.

34 Tłumaczenie własne.
} 
Anno dominice incarnationis millesimo XXXII. Inperator natale Domini Goslarie gloriose peregit et pascha Seligenstad. Hoc anno predictus Bezbriem ob inmanissimam sue tirannidis seviciam a suis interfectus est machinatione fratrum suorum, sicut populi sermo est. Statim Miseco domum rediit cognoscens que, sibi propter immoderatam insolentiam omnia, que perpesus est, divino iudicio evenisse, misit ad inperatorem et tempus se prestandi digneque satisfaciendi postulavit. Quem imperator clementius, quam ipse opinaretur, suscepit eique et patrueli eius Theoderico regnum, quod ipse prius possederat, divisit, quod tamen solus iterum usurpavit ${ }^{35}$.

W tłumaczeniu polskim tekst ten brzmi następująco:

„Roku wcielenia pańskiego tysiąc 32 cesarz Urodziny Pańskie w Goslarze sławnie spędził, a Wielkanoc w Selingstadt. Tegoż roku wcześniej wymieniony Bezprym z powodu ogromnego okrucieństwa swojej tyranii został zabity przez swoich, i również nie bez wpływu swoich braci, według istniejącej pogłoski ludu. Mieszko natychmiast do domu powrócił. Rozumiejąc, że zdarzyło mu się słusznie, wszystko co przeżył w poprzednich latach za sprawą sądu bożego, wysłał do cesarza i domagał się /wyznaczenia/ czasu przybycia i stosownego zadośćuczynienia. Cesarz go, łagodniej niż on sam sądził, przyjął i jego stryjowi pewnemu Theoderykowi królestwo podzielił. On to później sam znowu dla siebie zawłaszczył".

Dwunastowieczny kronikarz znany jako Annalista Saxo powtarza informacje za Rocznikami hildesheimskimi. Jednocześnie jednak ogranicza jej znaczenie informując, że jest to plotka - bo tak chyba można rozumieć owe sicut populi sermo est. Mieszko uznaje, że jego klęska była spowodowana Sądem Bożym. Nie ma też tu wzmianki o koronie Mieszka, nawet w formie, w jakiej pojawia się w Rocznikach hildesheimskich. Rocznikarze są zgodni, co do zasadniczych elementów zdarzeń.

Kolejnym źródłem omawiającym interesujące zagadnienie są powstałe w latach 1046-1047 Chwalebne czyny cesarza Konrada II Wipona. Jest to odmienna od rocznikarskiej wizja interesujących nas wydarzeń. Przytaczam poniżej interesujący nas fragment tego tekstu wraz z tłumaczeniem:

Supra dictus Bolizlaus dux Bolanorum mortuus reliquit duos filios, Misiconem et Ottonem. Misico dum fratrem suum Ottonem peresequeretur, expulerat eum in Ruzziam. Dum ibi aliquantum tempus miserabiliter viveret, coepit rogare gratiam imperatoris Chuonradi, ut ipso impetrante et iuvante restitueretur patriae suae.. Quod dum imperator facere vellet, decrevit, ut ipse cum copiis ex una parte, ex altera frater Otto Misiconem aggrederentur. Hunc impetum Misico ferre non valens fugit in Boemiam ad Uodalricum ducem, cui tunc temporis imperator iratus fuerat. Sed ille, ut

${ }^{35}$ Die Reichschronik des Annalista Saxo, wyd. K. Nass, MGH SS, t. 37, Hannover 2006, s. 369. 
sic placaret imperatorem, voluit sibi reddere Misiconem ; quod pactum sceleratum renuit caesar, dicens se nolle inimicum emere ab inimico. Otto restitutus patriae et dux factus a caesare, dum post aliquod tempus minus caute ageret, a quodam familiari suo clam interfectus est. Tunc Misico omnibus modis quaerebat gratiam imperatricis Giselae et reliquorum principum, ut mereretur redire ad gratiam imperatoris. Caesar misericordia motus dedit sibi veniam et divisa provincia Bolanorum in tres partes Misiconem fecit tetrarcham, reliquas duas duobus aliis commendavit ; sic imminuta potestate minor facta est temeritas. Defuncto Misicone Gazmerus filius eius fideliter serviebat huc usque imperatoribus nostris ${ }^{36}$.

W tłumaczeniu Ewy Milkamanowicz tekst ten brzmi:

„Wspomniany wcześniej Bolesław, książę Polaków, zmarł pozostawiwszy dwóch synów: Mieszka i Ottona. Mieszko, gdy prześladował swego brata Ottona, przepędził go na Ruś. Kiedy tam jakiś czas nędznie żył, zaczął prosić cesarza Konrada o okazanie mu łaski, by za jego wstawiennictwem i pomocą został przywrócony do ojczyzny. Cesarz wyraził na to zgodę i postanowił, że razem zaatakują Mieszka, $z$ jednej strony on sam z wojskiem, z drugiej zaś brat Otto. Ponieważ Mieszko nie mógł wytrzymać tego napadu, uciekł do Czech do księcia Udalryka, z którym cesarz wówczas był poróżniony. Okazało się, że Udalryk pragnąc pojednania z cesarzem, chciał wydać Mieszka. Cesarz nie wyraził zgody na zawarcie tego haniebnego układu mówiąc, iż nie chce kupować nieprzyjaciela od nieprzyjaciela. Otto przywrócony ojczyźnie i ustanowiony księciem przez cesarza, zachowując się po jakimś czasie niezbyt ostrożnie został skrycie zabity przez kogoś ze swojego otoczenia. Wówczas Mieszko na różne sposoby próbował wyjednać łaskę u cesarzowej Gizeli i u pozostałych książąt, aby zasłużyć na powrót do łaski cesarza. Cesarz kierowany miłosierdziem udzielił mu łaski i podzieliwszy kraj Polaków na trzy części Mieszka mianował tetrarchą, dwie pozostałe części nadał dwóm innym osobom. Ograniczywszy w ten sposób, poskromił nieco ich zuchwałość. Po śmierci Mieszka jego syn Kazimierz wiernie służył aż do tego czasu naszym cesarzom"37.

Należy zauważyć, że system tetrarchii opiera się na czwórwładzy i był stosowany w Rzymie po reformach Dioklecjana. Wipon jednak informuje o podziale państwa Mieszka II na trzech władców. Trudno ocenić, czy jest to błąd, czy też Wipon rozumie to w ten sposób, że Mieszko dostał tylko 1/4 dotychczasowego obszaru państwa.

Sojusznika cesarza, najmłodszego z braci Ottona spotkał wedle Wipona podobny jak Bezpryma los. Został zamordowany przez kogoś ze swojego

\footnotetext{
${ }^{36}$ Wipo, Gesta Chuonradi, s. 48-49. Jest to fragment XXIX rozdziału Gesta Chuonradi. Wersję łacińską przytacza też wydanie: Wipon, Chwalebne czyny cesarza Konrada. Gesta Chuonradi II imperatoris, wstęp J. Sochacki, tłum. E. Milkamanowicz, tu s. 110.

37 Tłumaczenie wg.: Wipon, Chwalebne czyny, s. 55-57 (z moimi poprawkami).
} 
otoczenia. Jednak powodem miała być nieostrożność władcy, a nie jego okrucieństwo, jak to było w przypadku jego brata. W wersji Wipona to cesarz przywraca Mieszkowi władzę, zrozumiała jest więc pokora i gotowość na ustępstwa tego ostatniego, skoro wcześniej wszystko stracił. Działania cesarza są tu skuteczne. Mieszko tetrarcha musi dzielić się władzą z innymi. Syn jego Kazimierz już takich kłopotów cesarzom nie sprawia.

Najpełniejsza, jak widać, z przytoczonych relacji jest opowieść Wipona. Wiąże się to $z$ formą pisarską, która wymaga bardziej dopracowanej narracji niż zapiski rocznikarskie. Jako biograf i monografista w zakresie historii jest Wipon świadomym naśladowcą Salustiusza. Roczniki hildesheimskie przynoszą narrację znacznie mniej spójną niż u Wipona. Nie wiemy, jak Bezprym osiągnął sukces, wypędzając brata. Wiemy tylko, że całą akcję przeprowadził nagle. Żadne źródło nie wspomina o tym, że był pierworodnym synem Chrobrego, mimo że w tych okolicznościach taka wzmianka byłaby naturalna. Czyżby nie wiedziano o tym w cesarstwie? Prezentacja bardziej znanej na zachodzie postaci Ottona budzi też wiele wątpliwości. Raz pojawia się jako sojusznik Mieszka, raz zaś jako jego wróg. Czy te różnice wynikają z niewiedzy, czy też z niedbałego montażu znanych wiadomości? Według Roczników hildesheimskich Mieszko sam odzyskał utraconą władzę. Według Roczników altajskich to cesarz przywrócił mu władzę. Podobnie przedstawia te zdarzenia Wipon.

Jak można rekonstruować te zdarzenia? Jak pokazałem, Wipon układa historię Mieszka jako opowiadanie o zbrodni i karze. Narzędziem tej ostatniej jest Konrad II. Osiąga to przez pełne przywrócenie pokoju. Wersja reprezentowana głównie przez Roczniki hildesheimskie jest inna. Klęska w starciu z cesarzem nie wydaje się mieć decydującego znaczenia. Przyczynia się jednak do osłabienia Mieszka. Dlatego nagłe wystąpienie Bezpryma odnosi sukces. Ani to zwycięstwo, ani też powrót Mieszka nie dokonuje się przy pomocy obcej interwencji. Oba te zdarzenia przebiegają nagle - stąd podobne określenia - subito, statim. Otton zdaje się być sojusznikiem Mieszka, a nie przeciwnikiem. Jest to naturalne. Obaj pochodzą od tej samej matki. Jednocześnie Otton jest trzeci w kolejce do władzy. Przy obu starszych braciach żyjących nie ma na jej zdobycie szansy.

Przewrót dokonany przez Bezpryma opiera się o siły wewnętrzne. Rocznik nie potwierdza konstrukcji Wipona o wspólnym ataku na Mieszka Ottona i Konrada lub nawet Bezpryma i Konrada. 
Metodycznie nieuzasadnione jest więc łączenie ze sobą sprzecznych relacji Roczników hildesheimskich i Wipona. Wybierając jedną z nich warto pamiętać o błędach poczynionych przez Wipona, które są jasne na podstawie całego materiału źródłowego. Wipon z rozsianych informacji buduje zwartą narrację, która ma spełniać polityczne cele - gloryfikować Konrada II. Ze źródeł powołanych przez B. Śliwińskiego uznaję przeto za wątpliwej wartości dwa - relację Piotra Damianiego i Żywot Konrada II Wipona. Należy je weryfikować w oparciu o świadectwa bardziej wiarygodne, które jednak wypada poddać krytyce - Brunona $z$ Kwerfurtu, jako najbliższego omawianych zdarzeń i Roczników hildesheimskich.

Nie ma również źródłowej podstawy, aby łączyć wzmiankę w Powieści dorocznej o najeździe książąt Jarosława i Mścisława, skoro nie ma tam wzmianki o współpracy z Bezprymem, jak to widać w poniższym tekście:

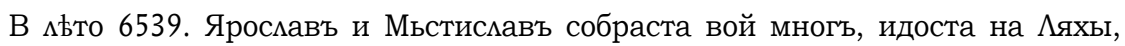
и заяста грады червеньскыя опять, и повоеваста Аядьскую землю, и многы мяхы приведоста, и раздъливша я. Ярославъ посади своя по Ръси, и суть до сего дне ${ }^{38}$.

Tłumaczenie polskie brzmi następująco:

„Roku 6539 [1031]. Jarosław i Mścisław zebrali wojów mnogich, poszli na Lachów, i zajęli Grody Czerwieńskie znowu, i spustoszyli ziemię lacką, i mnóstwo Lachów przywiedli, i rozdzielili ich. Jarosław osadził swoich nad Rosią i są do dziś dnia" 39 .

Nie ma tu mowy o współpracy z którymś z polskich książąt. Uprowadzenie polskiej ludności i odzyskanie Grodów Czerwieńskich to skutki tej wyprawy. Autor powołuje się tu na fakt osadzenia uprowadzonej ludności nad Rosią i zachowaniu tego osadnictwa aż po czasy mu współczesne. Jest to zatem tekst sprzeczny z informacją Wipona o ataku Ottona na Mieszka przeprowadzonym z Rusi. Rosyjscy badacze wskazują natomiast na kontekst, który niesie Powieść minionych lat ${ }^{40}$. Pod 6538 r. tj. 1030 znajdujemy tu następującą zapiskę:

38 Повесть временных мет, oprac. Д. С. Аихачёв, red. В. П. Адриановой-Перетц, Sankt-Petersburg 1991, s. 65.

39 Powieść minionych lat, przełożył i opracował F. Sielicki, Wrocław 1999, BN Seria II, nr 244, s. 117.

40 Повесть временных мет, s. 480. 
„Tego czasu umarł Bolesław Wielki w Lachach, i był bunt w ziemi lackiej: ludzie powstawszy pozabijali biskupów i popów, i bojarów swoich, i był u nich bunt" 41 .

Już A. Szachmatow odnosił tę zapiskę Powieści do zaginionego źródła Żywota Św. Antoniego. Błędna zapiska o śmierci Bolesława Chrobrego jest wedle tej koncepcji konstrukcją opartą o datację buntu pogańskiego w Polsce datowanego wedle relacji Mojżesza Węgrzyna na ten rok. Ten miał uciec z polskiej niewoli dzięki buntowi pogańskiemu w Polsce w 1030 r. Zatem wojna Rusi z Polską spowodowana byłaby wedle tej kalkulacji okazją, którą dawał bunt wewnętrzny. Nagły atak Bezpryma na Mieszka II przedstawiony w rocznikach niemieckich nie jest łączony w nich $z$ żadną ingerencją $z$ zewnątrz. Podobnie zamordowanie Bezpryma jest związane z reakcją wewnętrzną na jego postępowanie. Jeśli zaakceptujemy dewocyjne inklinacje Bezpryma poświadczone w Żywocie św. Romualda pióra Piotra Damianiego, to rzeczywiście trudno uznać Bezpryma za przywódcę pogan. Raczej odwrotnie, wolno w nim widzieć strażnika ortodoksji. Tłumaczyłoby to też antychrześcijańską reakcję.

Podsumowując te uwagi wypada po raz kolejny odnieść się do metody zastosowanej przez B. Śliwińskiego. Sklejanie powycinanych wiadomości źródłowych nie jest najlepszym sposobem uprawiania historii. Być może ta metoda wynika z wybranego sposobu prezentacji postaci Bezpryma. Sposób ten narzuca kształt wypracowanej przez historyka rekonstrukcji. Odtworzone dzieje pierworodnego syna Bolesława Chrobrego układają się zgodnie z logiką życiową i polityczną wytworzoną przez ten rodzaj narracji. Takie zdystansowanie się pozwala odrzucać nowe analizy zachowanych źródeł historycznych, jako niezgodne $z$ dotychczasową narracją. Warto zwrócić na to uwagę. Narracja buduje się sama, wynika z przyjętych założeń. Gdyby została rozbita przez wprowadzenie analizy zachowanych źródeł, przyniosłaby zapewne inny wynik. Kilka przykładów takiego postępowania przedstawiłem $\mathrm{w}$ tym artykule, nie wyczerpując jednak tematu. Można się z nimi nie zgadzać, ale żeby je obalić trzeba powrócić do analizy źródeł.

\footnotetext{
41 Powieść minionych lat, s. 117.
} 